\title{
OPEN Stress hormones promote DNA damage in human oral keratinocytes
}

\author{
Vitor Bonetti Valente ${ }^{1}$, Diovana de Melo Cardoso ${ }^{1}$, Giseli Mitsuy Kayahara ${ }^{1,2}$, \\ Giovana Barros Nunes ${ }^{3}$, Kellen Cristine Tjioe ${ }^{1,4}$, Éder Ricardo Biasoli, ${ }^{1,2}$, \\ Glauco Issamu Miyahara ${ }^{1,2}$, Sandra Helena Penha Oliveira ${ }^{1,4}$, Gisele Zoccal Mingoti ${ }^{3}$ \& \\ Daniel Galera Bernabé ${ }^{1,2} \bowtie$
}

Chronic stress increases the systemic levels of stress hormones norepinephrine and cortisol. As well as tobacco-specific carcinogen NNK (4-(methylnitrosamine)-1-(3-pyridyl)-1-butanone), they can induce expressive DNA damage contributing to the cancer development. However, it is unknown whether stress hormones have genotoxic effects in oral keratinocytes. This study investigated the effects of stress hormones on DNA damage in a human oral keratinocyte cell line (NOK-SI). NOK-SI cells stimulated with norepinephrine or cortisol showed higher DNA damage compared to untreated cells. Norepinephrine-induced DNA damage was reversed by pre-treatment with beta-adrenergic blocker propranolol. Cells treated with NNK combined to norepinephrine displayed reduced levels of caspases 3 and 7. Cortisol also reduced the activity of pro-apoptotic enzymes. NNK or norepinephrine promoted single-strand breaks and alkali-label side breaks in the DNA of NOK-SI cells. Pre-treatment of cells with propranolol abolished these effects. Carcinogen NNK in the presence or absence of cortisol also induced DNA damage of these cells. The genotoxic effects of cortisol alone and hormone combined with NNK were blocked partially and totally, respectively, by the glucocorticoid receptor antagonist RU486. DNA damage promoted by NNK or cortisol and carcinogen combined to the hormone led to intracellular $\mathrm{yH} 2 \mathrm{AX}$ accumulation. The effects caused by NNK and cortisol were reversed by propranolol and glucocorticoid receptor antagonist RU486, respectively. Propranolol inhibited the oxidation of basis induced by NNK in the presence of DNA-formamidopyrimidine glycosylase. DNA breaks induced by norepinephrine in the presence or absence of NNK resulted in higher $80 \mathrm{HdG}$ cellular levels. This effect was also induced through beta-adrenergic receptors. Together, these findings indicate that stress hormones induce DNA damage of oral keratinocytes and could contribute to oral carcinogenesis.

Psychological stress activates the Sympathetic Nervous System (SNS) and the Hypothalamic-Pituitary-Adrenal (HPA) axis up-regulating the circulating levels of stress hormones ${ }^{1}$. The activation of SNS increases the production of catecholamines norepinephrine and epinephrine while HPA axis induces the cortisol secretion ${ }^{1}$. Exposure to these hormones released from chronic stress response has been associated to an enhanced risk of developing diseases such as cancer ${ }^{1,2}$. In somatic cells, norepinephrine and cortisol may induce DNA damage through the activation of beta-adrenergic and glucocorticoid receptors, respectively ${ }^{3,4}$. Both mechanisms trigger similar effects to those produced by the tobacco smoke carcinogens ${ }^{5,6}$. A significant damage in the integrity of DNA unleashed by these substances may lead to genome mutations and affect oncogenic mechanisms predisposing to cell malignant transformation ${ }^{2,5}$.

Chronic stress and stress hormones may cause a significant DNA damage accompanied by a higher production of phosphorylated histone $\mathrm{H} 2 \mathrm{AX}(\gamma \mathrm{H} 2 \mathrm{AX})^{7,8}$ and 8-hydroxy-2'-deoxyguanosine $(8 \mathrm{OHdG})^{2,9}$. Both molecules are

\footnotetext{
${ }^{1}$ Psychoneuroimmunology Laboratory, Psychosomatic Research Center, Oral Oncology Center, School of Dentistry, São Paulo State University (Unesp), 1193 José Bonifácio St, Araçatuba, São Paulo 15050-015, Brazil. 'Department of Diagnosis and Surgery, School of Dentistry, São Paulo State University (Unesp), 1193 José Bonifácio St, Araçatuba, São Paulo 15050-015, Brazil. ${ }^{3}$ Laboratory of Reproductive Physiology, Department of Animal Health, School of Veterinary Medicine, São Paulo State University (Unesp), 793 Clovis Pestana St, Araçatuba, São Paulo 16050-680, Brazil. 'Laboratory of Immunopharmacology, Department of Basic Sciences, School of Dentistry, São Paulo State University (Unesp), 1193 José Bonifácio St, Araçatuba, São Paulo 15050-015, Brazil. ${ }^{\boxplus}$ email: daniel.bernabe@unesp.br
} 
A

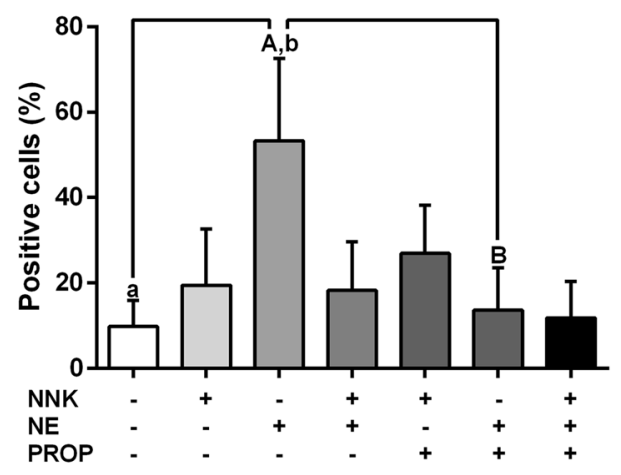

B

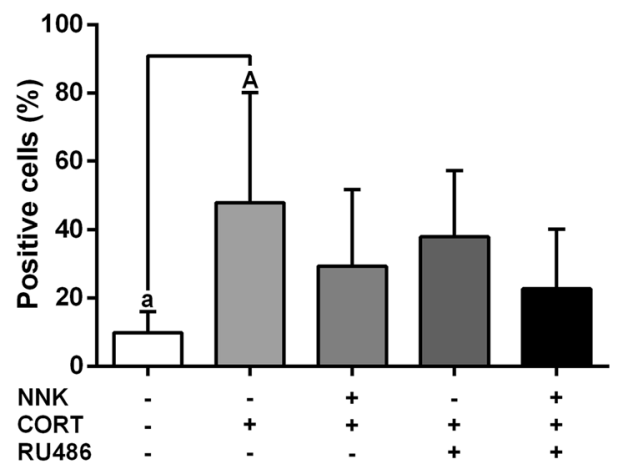

Figure 1. Stress hormones promote DNA damage in oral keratinocytes. (A) Norepinephrine increased the DNA damage in oral epithelial cells and this effect was abolished by the non-selective beta-blocker propranolol. (B) Cortisol increased the DNA fragmentation of oral keratinocytes. The results are expressed as the mean \pm standard deviation (SD). Upper- and lower cases equal letters indicate a statistically significant difference $(p<0.05)$. NNK $=4$ (N-metil-N-nitrosamine)-1-(3-piridil)-butano-1-one). NE= norepinephrine. $\mathrm{PROP}=$ propranolol. CORT $=$ cortisol. NNK, NE, PROP and RU486 were used at $10 \mu \mathrm{M}$. CORT was used at $100 \mathrm{nM}$. NOK-SI cells were exposed to NNK and/or stress hormones in the presence or absence of their antagonists for $72 \mathrm{~h}$.

considered mutagenic biomarkers of the DNA damage and significantly enhance the occurrence of tumorigenic mutations into the genome of somatic cells, which may become malignant ${ }^{2,10}$. Moreover, stress hormones can inhibit the apoptosis of somatic cells ${ }^{11,12}$ allowing their replication with DNA damage. This inhibition is also considered another crucial mechanism related to the acquisition of malignant phenotype ${ }^{2,3}$. The activity of caspases is measured to assess cell apoptosis and may become downregulated after chronic exposure to the stress hormones and carcinogenic agents ${ }^{13,14}$.

Oral cancer represents one of the most common malignancies worldwide and its occurrence has been widely associated to the tobacco smoking ${ }^{15}$. In addition, chronic stress and stress hormones have also been investigated in oral cancer patients and preclinical models of the disease ${ }^{16-20}$. We recently demonstrated that biobehavioral factors are related to increased circulating norepinephrine levels in these patients ${ }^{16}$. In an orthotopic model, chronic stress up-regulated the plasma levels of catecholamines and glucocorticoids, which would contribute to increase tumor size and invasiveness ${ }^{17}$. In rats underwent chemical carcinogenesis, we showed that the stress hormones levels in the normal microenvironment predict the risk of developing oral cancer ${ }^{18}$. An expressive DNA damage caused by the chemical substances such as nicotine and tobacco-specific nitrosamines may be considered one of the first molecular events for oral cancer occurrence ${ }^{5}$. However, it remains unknown whether stress hormones have genotoxic effects in oral epithelial cells.

In the current study, we tested the hypothesis that the chronic exposure of an oral keratinocyte cell line (NOKSI) to the stress hormones in the presence or absence of chemical carcinogen NNK (4-(methylnitrosamine)-1(3-pyridyl)-1-butanone), a tobacco-specific nitrosamine, would induce DNA damage. In addition, these cells were also evaluated for the production of molecules associated to DNA damage and apoptosis.

\section{Results}

Norepinephrine and cortisol induce DNA damage in oral epithelial cells. TUNEL assay was performed to evaluate whether carcinogen NNK and stress hormones would promote a severe DNA fragmentation at the terminal deoxynucleotidyl transferase dUTP nick-end in NOK-SI cells. After $72 \mathrm{~h}$ of treatment, NOK-SI cells stimulated with norepinephrine displayed higher percentage of positive-TUNEL cells than untreated group $(p<0.0001$; Fig. 1A). Norepinephrine-induced DNA damage was blocked by the pre-treatment with nonselective beta-blocker propranolol $(p<0.0001$; Fig. 1A). Cells stimulated with cortisol showed an increase of the DNA damage when compared to control cells $(p=0.0004$; Fig. 1B). This effect was partially abolished by the glucocorticoid receptor antagonist RU486 ( $p>0.05$; Fig. 1B). NNK treatment did not induced a significant DNA fragmentation when compared to the untreated group $(p>0.05$; Fig. 1A). However, stimulation with carcinogen NNK inhibited the genotoxic effect induced by the stress hormones $(p>0.05$; Fig. 1A, B).

Cortisol inhibits the activity of apoptotic enzymes in oral keratinocytes. The effects of NNK and stress hormones on the activity of caspases 3 and 7 were measured in NOK-SI cells. Carcinogen NNK or norepinephrine did not change the levels of caspases concerning the untreated group $(p>0.05$; Fig. $2 \mathrm{~B}, \mathrm{C}, \mathrm{H})$. Nevertheless, cells treated with NNK combined to the norepinephrine showed lower levels of the apoptotic enzymes $(p<0.0001$; Fig. 2D, H). Cells treated with cortisol displayed lower levels of caspases 3 and 7 than untreated cells $(p<0.0001$; Fig. 2J, N). However, this effect was not inhibited by the glucocorticoid receptor antagonist RU486 $(p>0.05$; Fig. $2 \mathrm{~L}, \mathrm{~N})$. 


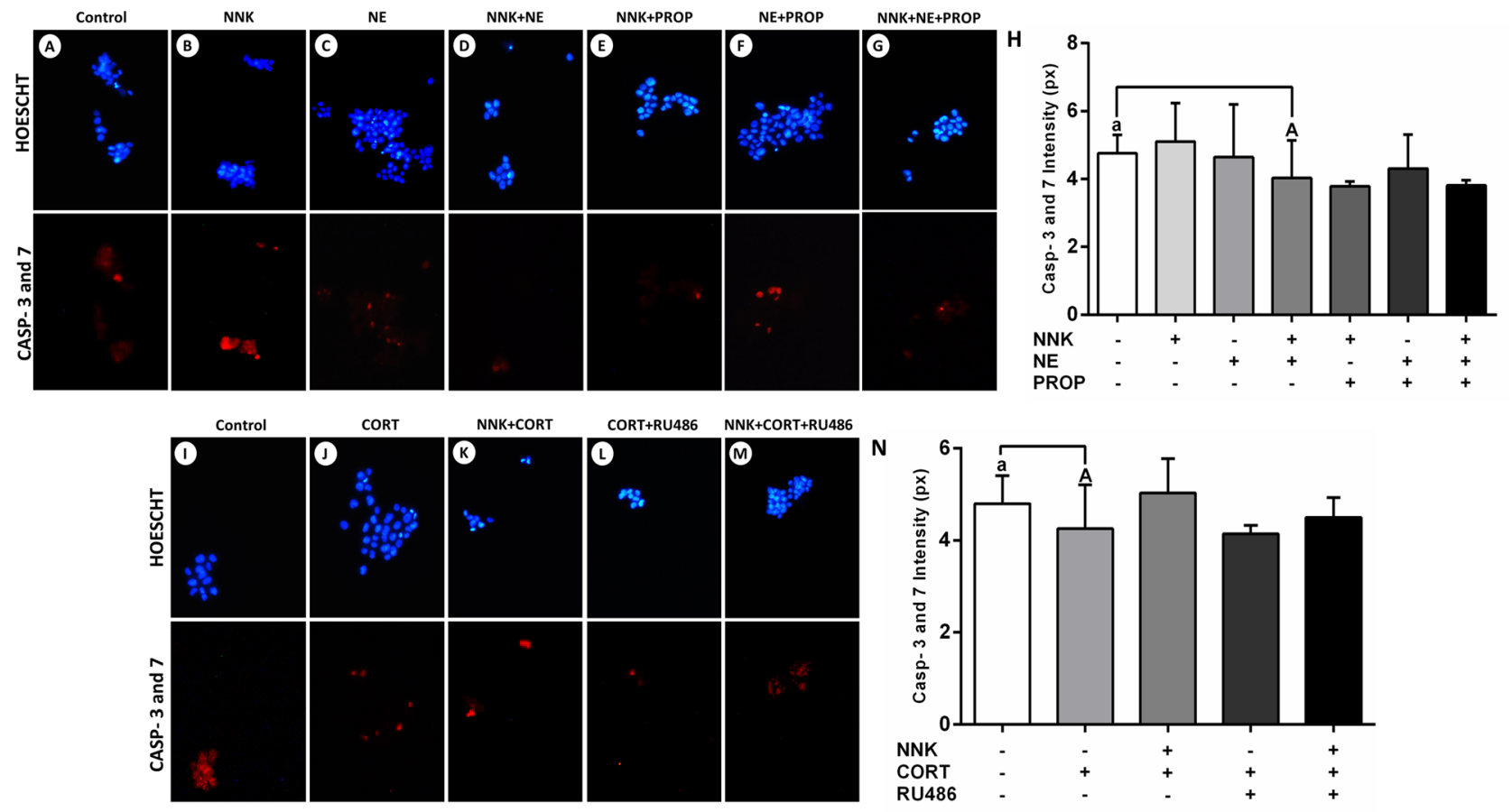

Figure 2. Effects of tobacco-specific nitrosamine NNK and norepinephrine on the activity of the caspases 3 and 7. (A) Control. (B) NNK. (C) Norepinephrine. (D) NNK and norepinephrine. (E) NNK and propranolol. (F) Norepinephrine and propranolol. (G) NNK, norepinephrine and propranolol. (H) Combined treatment of NNK with norepinephrine inhibited the activity of the pro-apoptotic enzymes. This effect was not abolished by the beta-adrenergic blocker propranolol. Cortisol inhibits the activity of caspases 3 and 7. (I) Control. (J) Cortisol. (K) NNK and cortisol. (L) Cortisol and RU486. (M) NNK, cortisol and RU486. (N) Cortisol inhibited the activity of pro-apoptotic enzymes. This effect was not abolished by the glucocorticoid receptor blocker RU486. The results are expressed as the mean \pm standard deviation (SD). Upper- and lower cases equal letters indicate a statistically significant difference $(p<0.0001)$. NNK $=4$ ( $\mathrm{N}$-metil-N-nitrosamine)-1-(3-piridil)-butano-1-one). $\mathrm{NE}=$ norepinephrine. $\mathrm{PROP}=$ propranolol. $\mathrm{CORT}=$ cortisol. $\mathrm{NNK}, \mathrm{NE}, \mathrm{PROP}$ and RU486 were used at $10 \mu \mathrm{M}$. CORT was used at $100 \mathrm{nM}$. NOK-SI cells were exposed to NNK and/or stress hormones in the presence or absence of their antagonists for $72 \mathrm{~h}$.

Stress hormones promote single-strand breaks and alkali-label side breaks in the DNA of oral epithelial cells. The effects of NNK and stress hormones on single-strand breaks and alkali-label side breaks in the DNA of NOK-SI cells were assessed using the comet assay. After $72 \mathrm{~h}$ of exposure, cells treated with NNK or norepinephrine showed an increased DNA damage compared to untreated cells $(p<0.0001$; Fig. 3B, C, I). These effects were abolished by the beta-adrenergic antagonist propranolol $(p<0.0001$; Fig. 3E, F, I). Treatment with norepinephrine associated to NNK did not induce significant DNA damage of NOK-SI cells $(p>0.05$; Fig. 3D, I). Furthermore, an increased tail DNA percentage was observed in cells treated with cortisol alone and cortisol associated with NNK when compared to control cells $(p<0.0001$; Fig. 3K, L, P). Pre-treatment of NOKSI cells with glucocorticoid receptor antagonist RU486 inhibited partially and totally the genotoxic effects of cortisol alone and glucocorticoid combined with NNK, respectively $(p>0.05 ; p<0.0001$; Fig. 3M, N, P).

DNA damage induced by tobacco-derived nitrosamine NNK and cortisol in oral keratinocytes is associated with intracellular $\mathrm{yH} 2 \mathrm{AX}$ accumulation. Immunofluorescence assays were performed to assess the $\gamma \mathrm{H} 2 \mathrm{AX}$ cellular accumulation levels in NOK-SI cells stimulated with NNK and stress hormones. After $4 \mathrm{~h}$ of stimulation, cells treated with NNK displayed an increase in the $\gamma \mathrm{H} 2 \mathrm{AX}$ accumulation when compared to untreated cells $(p<0.0001$; Fig. $4 \mathrm{~B}, \mathrm{H})$. The NNK-induced $\gamma \mathrm{H} 2 \mathrm{AX}$ accumulation was inhibited by the pre-incubation with beta-adrenergic antagonist propranolol $(p<0.0001$; Fig. 4E, H). NOK-SI cells stimulated only with norepinephrine did not display significant changes in the $\gamma \mathrm{H} 2 \mathrm{AX}$ accumulation when compared to control cells $(p>0.05 ;$ Fig. $4 \mathrm{C}, \mathrm{H})$. On the other hand, cells treated only with cortisol or hormone combined with NNK showed a higher $\gamma \mathrm{H} 2 \mathrm{AX}$ accumulation when compared to untreated cells $(p<0.0001$; Fig. $4 \mathrm{~J}, \mathrm{~K}, \mathrm{~N})$. Preincubation with glucocorticoid receptor antagonist RU486 inhibited these genotoxic effects ( $p<0.0001$; Fig. 4L, $\mathrm{M}, \mathrm{N})$.

Tobacco-specific carcinogen NNK induces the oxidation of basis in the DNA of oral epithelial cells. To evaluate the oxidation of basis induced by the carcinogen NNK and stress hormones in the DNA of NOK-SI cells, FPG-sensitive sites were identified by modified comet assay. After $72 \mathrm{~h}$ of treatment, cells stimulated with NNK displayed an increase in the tail DNA percentage when compared to untreated cells $(p<0.0001$; 

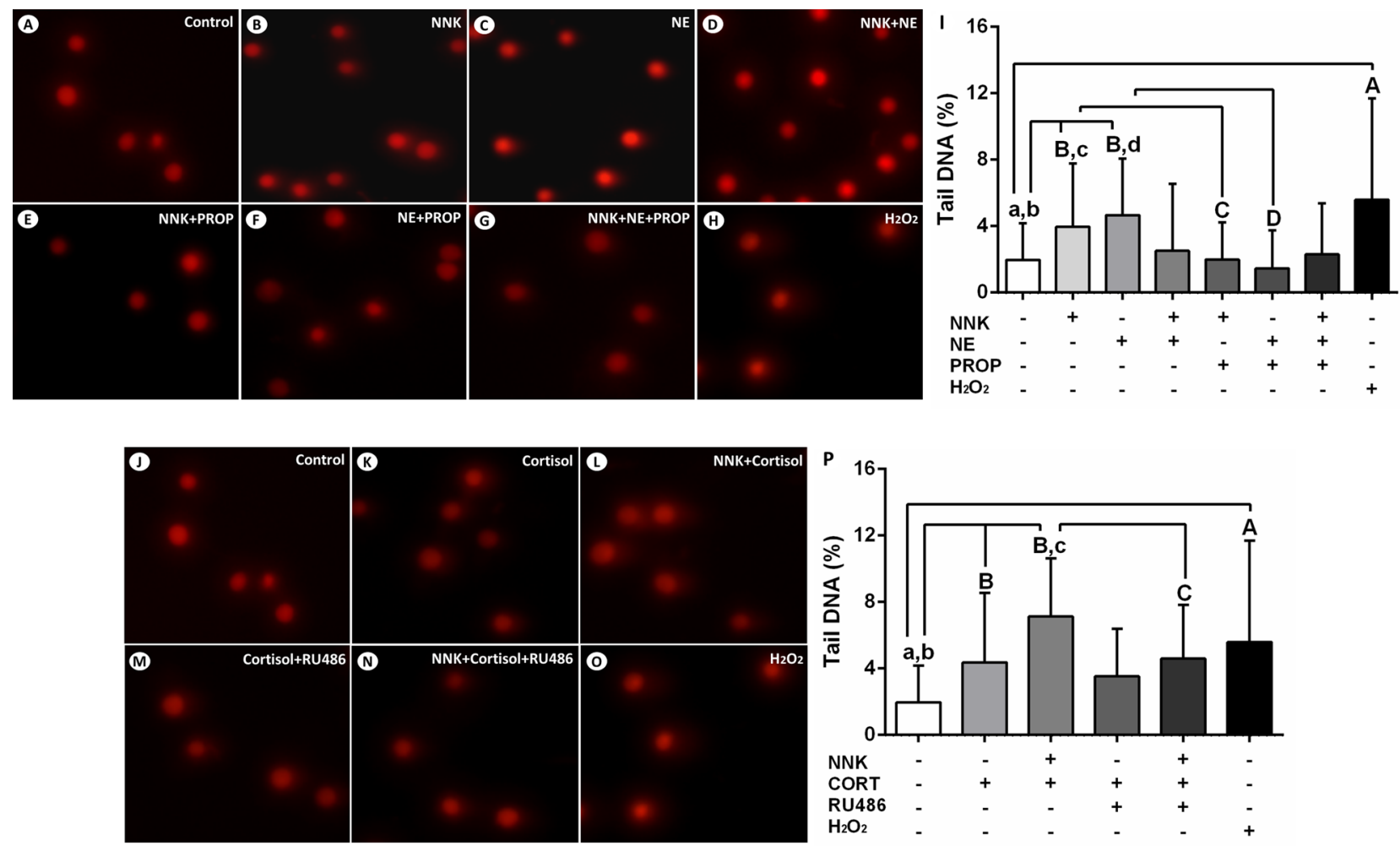

Figure 3. Stress hormones and NNK induce single-strand breaks and alkali-label side breaks in the DNA of oral epithelial cells. (A) Control. (B) NNK. (C) Norepinephrine. (D) NNK and norepinephrine. (E) NNK and propranolol. (F) Norepinephrine and propranolol. (G) NNK, norepinephrine and propranolol. ( $\mathbf{H}_{\text {) }} \mathrm{H}_{2} \mathrm{O}_{2}$ (positive control). (I) $\mathrm{H}_{2} \mathrm{O}_{2}$, NNK or norepinephrine increased DNA damage of NOK-SI cells. These effects were inhibited by the beta-adrenergic antagonist propranolol. Combined treatment of NNK and norepinephrine did not induce significant genotoxic effects. Cortisol enhanced the DNA damage of oral keratinocytes in the presence or absence of NNK. (J) Control. (K) Cortisol. (L) NNK and cortisol. (M) Cortisol e RU486. (N) NNK, cortisol and RU486. (O) $\mathrm{H}_{2} \mathrm{O}_{2}$ (positive control). (P) $\mathrm{H}_{2} \mathrm{O}_{2}$, cortisol alone and glucocorticoid associated with NNK increased the DNA damage of NOK-SI cells. Glucocorticoid receptor antagonist RU486 reduced partially and totally the DNA damage induced by the cortisol alone and glucocorticoid combined with NNK, respectively. The results are expressed as the mean \pm standard deviation (SD). Upper- and lower cases equal letters indicate a statistically significant difference $(p<0.0001) . \mathrm{H}_{2} \mathrm{O}_{2}=$ hydrogen peroxide. $\mathrm{NNK}=4(\mathrm{~N}-$-metil-Nnitrosamine)-1-(3-piridil)-butano-1-one). $\mathrm{NE}=$ norepinephrine. $\mathrm{PROP}=$ propranolol. $\mathrm{CORT}=$ cortisol. $\mathrm{NNK}$, NE, PROP and RU486 were used at $10 \mu \mathrm{M}$. CORT was used at $100 \mathrm{nM}$. NOK-SI cells were exposed to NNK and/or stress hormones in the presence or absence of their antagonists for $72 \mathrm{~h}$.

Fig. 5B, I). This effect was abolished by the beta-adrenergic antagonist propranolol $(p<0.0001$; Fig. 5E, I). Norepinephrine alone or combined with NNK did not induce significant oxidation of basis compared to control ( $p>0.05$; Fig. 5C, D, I). Cells treated with cortisol in the presence or absence of NNK did not show significant changes regarding the oxidative damage $(p>0.05$; Fig. $5 \mathrm{~K}, \mathrm{~L}, \mathrm{P})$.

Norepinephrine increases the $80 \mathrm{HdG}$ levels in the presence or absence of carcinogen NNK in oral keratinocytes. To assess oxidative DNA damage levels induced by stress hormones in NOK-SI cells, the $8 \mathrm{OHdG}$ concentrations were measured in the cell culture medium. After $4 \mathrm{~h}$ of treatment, cells stimulated only with norepinephrine or hormone associated to the carcinogen NNK secreted higher 8OHdG levels in the culture supernatant compared to untreated cells $(p<0.0001$; Fig. 6A). Treatment with the hormone alone resulted in an approximately four-fold increase in the $8 \mathrm{OHdG}$ levels. The effects of norepinephrine alone or combined with NNK on the $8 \mathrm{OHdG}$ levels were abolished partially and totally by the beta-adrenergic antagonist propranolol, respectively ( $p<0.05 ; p<0.001$; Fig. 6A). NOK-SI cells treated with carcinogen NNK showed no significant changes in the $8 \mathrm{OHdG}$ levels when compared to untreated cells $(p>0.05$; Fig. $6 \mathrm{~A})$. Cortisol did not change the $8 \mathrm{OHdG}$ levels secreted by the oral keratinocytes when compared to non-stimulated cells $(p>0.05$; Fig. 6B).

\section{Discussion}

Investigations have showed that stress hormones may act on oral cancer promoting tumor cell proliferation and invasion $^{17-20}$. Although our previous studies have suggested that psychological stress and related hormones may predict oral carcinogenesis in a preclinical model ${ }^{18,21}$, the mechanisms associated with stress-induced malignant transformation of oral epithelial cells were unknown. In the current study, we used the NOK-SI cell line 

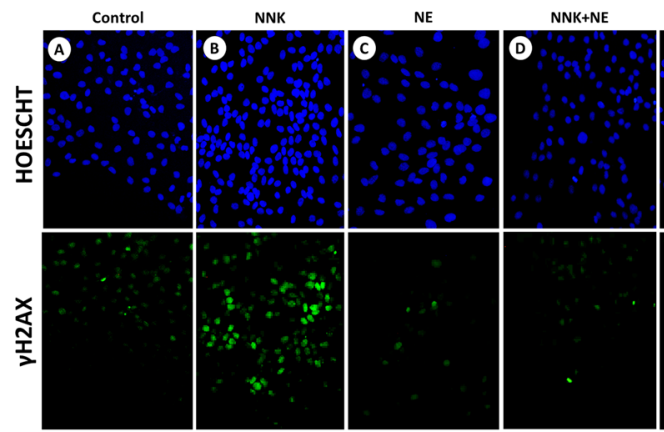

NNK+PROP
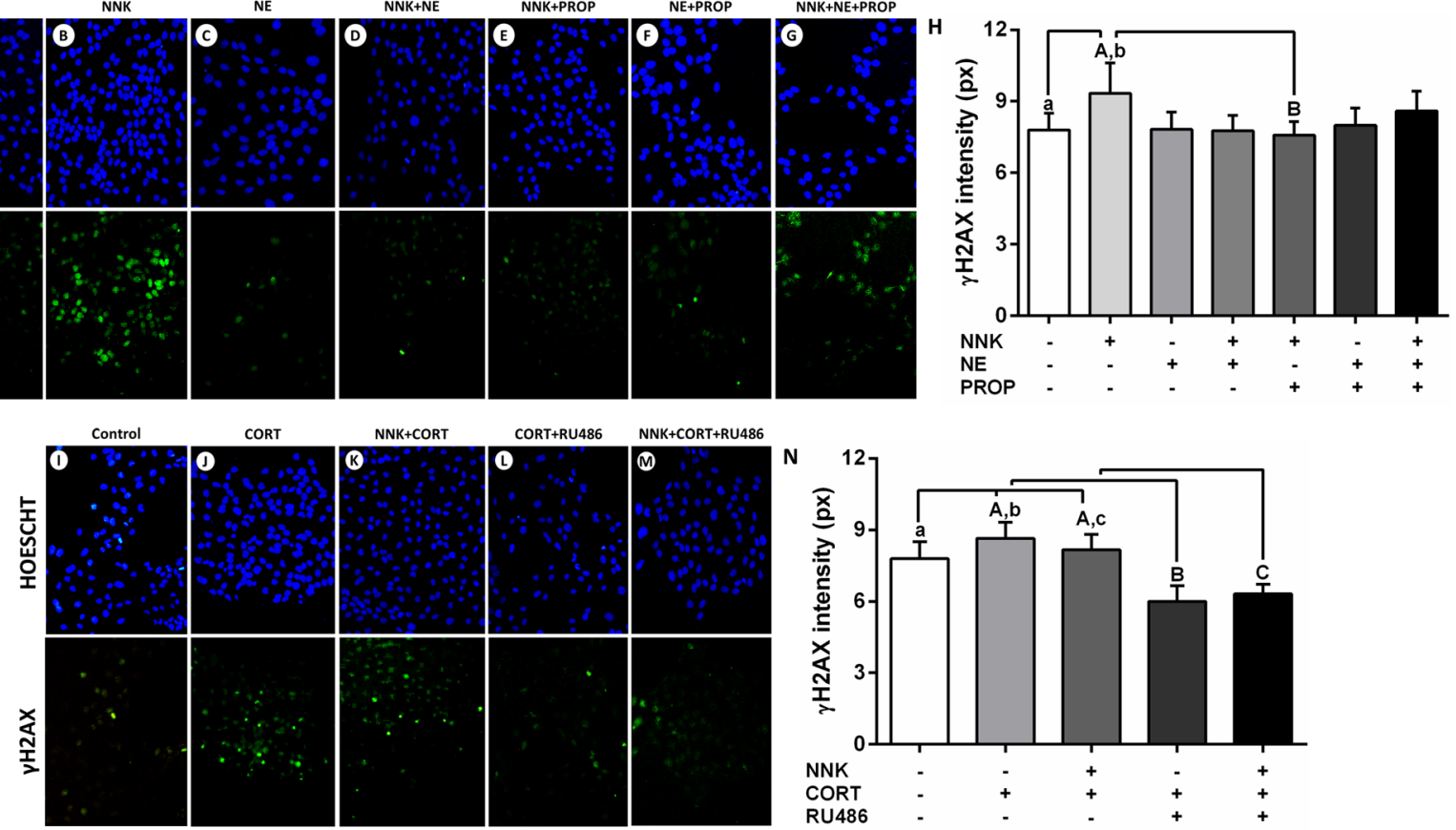

NNK+CORT

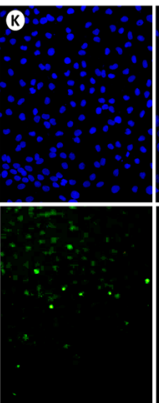

CORT+RU486
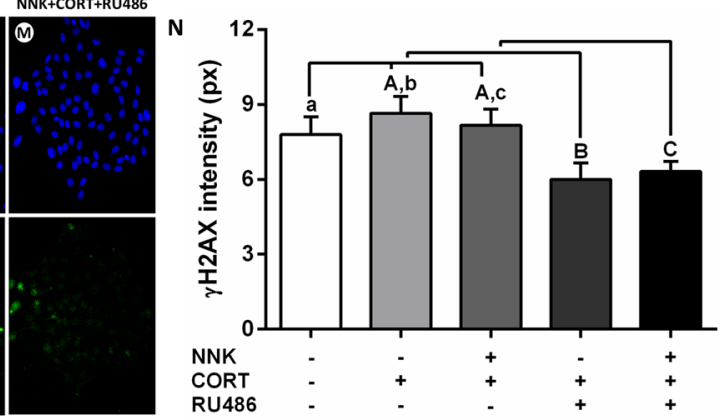

Figure 4. Exposure to the $\mathrm{NNK}$ and norepinephrine and $\gamma \mathrm{H} 2 \mathrm{AX}$ nuclear expression in oral keratinocytes. (A) Control. (B) NNK. (C) Norepinephrine. (D) NNK and norepinephrine. (E) NNK and propranolol. (F) Norepinephrine and propranolol. (G) NNK, norepinephrine and propranolol. (H) NNK increased the $\gamma \mathrm{H} 2 \mathrm{AX}$ nuclear expression levels. Beta-blocker propranolol inhibited the increased DNA damage caused by the carcinogen. Cortisol increased the $\gamma \mathrm{H} 2 \mathrm{AX}$ nuclear expression in oral epithelial cells. (I) Control. (J) Cortisol. (K) NNK and cortisol. (L) Cortisol and RU486. (M) NNK, cortisol and RU486. (N) Cortisol increased the $\gamma \mathrm{H} 2 \mathrm{AX}$ nuclear expression levels in the presence or absence of carcinogen NNK. Glucocorticoid receptor blocker RU486 inhibited the increased DNA damage caused by the hormone. The results are expressed as the mean \pm standard deviation (SD). Upper- and lower cases equal letters indicate a statistically significant difference $(p<0.0001)$. $\mathrm{NNK}=4(\mathrm{~N}$-metil-N-nitrosamine)-1-(3-piridil)-butano-1-one). $\mathrm{NE}=$ norepinephrine. $\mathrm{PRO} p=$ propranolol. CORT $=$ cortisol. NNK, NE, PROP and RU486 were used at $10 \mu \mathrm{M}$. CORT was used at $100 \mathrm{nM}$. NOK-SI cells were exposed to NNK and/or stress hormones in the presence or absence of their antagonists for $72 \mathrm{~h}$.

to confirm the hypothesis that stress hormones and tobacco-specific nitrosamine NNK promote DNA damage and reduce the apoptotic activity of human oral keratinocytes. Our results demonstrated that norepinephrine acted on beta-adrenergic receptors while cortisol activated the glucocorticoid receptor to produce tumorigenic effects in the NOK-SI cells. In this context, we showed the genotoxic action of stress hormones in the presence or absence of NNK, which has not yet been demonstrated in oral keratinocytes.

The role of stress hormones on the promotion of malignant phenotype in normal cells has been increasingly investigated in recent years $\mathrm{s}^{2-4,7,22-26}$. In these cells, DNA damage is considered a crucial event to trigger the malignant transformation ${ }^{2,5}$. After several cell divisions, an accumulation of damaged DNA may result in irreversible genome mutations commonly found in tumor cells ${ }^{2}$. In the current study, norepinephrine induced an expressive DNA damage of human oral keratinocytes. Similarly, some evidence also show that this adrenergic hormone has also genotoxic effects in normal cells, which may contribute to the tumorigenesis. Flint et al. ${ }^{4}$ demonstrated that norepinephrine at stress concentrations promoted DNA damage in mouse fibroblasts and this effect was abolished by using beta-adrenergic blocker propranolol. Likewise, we induced DNA damage of oral epithelial cells after norepinephrine exposure and reversed this effect with the beta-adrenergic blocker use. Some signaling pathways by which norepinephrine could be promoting DNA damage have been suggested. In a study, norepinephrine treatment promoted DNA damage of normal and cancer cells via PI3K/AKT/MDM2/p53 signaling pathway ${ }^{7}$. Sun et al..$^{22}$ also demonstrated that exposure to norepinephrine can induce DNA damage of embryonic stem cells through the activation of cyclic $3^{\prime}-5^{\prime}$ adenosine monophosphate (cAMP) and protein kinase A (PKA), molecules that constitute the cAMP/PKA pathway. Similarly to our study, these investigations also used norepinephrine at $10 \mu \mathrm{M}$ to produce an increased DNA damage, which may be considered a high concentration that simulate chronic stress conditions. We previously demonstrated that norepinephrine at $10 \mu \mathrm{M}$ enhanced the proliferation of oral cancer cells ${ }^{19}$.

Activation of the beta-adrenergic receptors by the norepinephrine can result in the upregulation of cAMP/ PKA pathway, which increases mitochondrial oxidative phosphorylation and reactive oxygen species (ROS) production $^{2,27}$. ROS may damage mitochondrial and nuclear DNA and produce a wide range of DNA lesions such as strand breaks, thymine glycol, base loss and base damage including $8 \mathrm{OHdG}^{2}$. In the current study, norepinephrine induced single-strand breaks and alkali-label side breaks in the DNA of NOK-SI cells. In addition, 

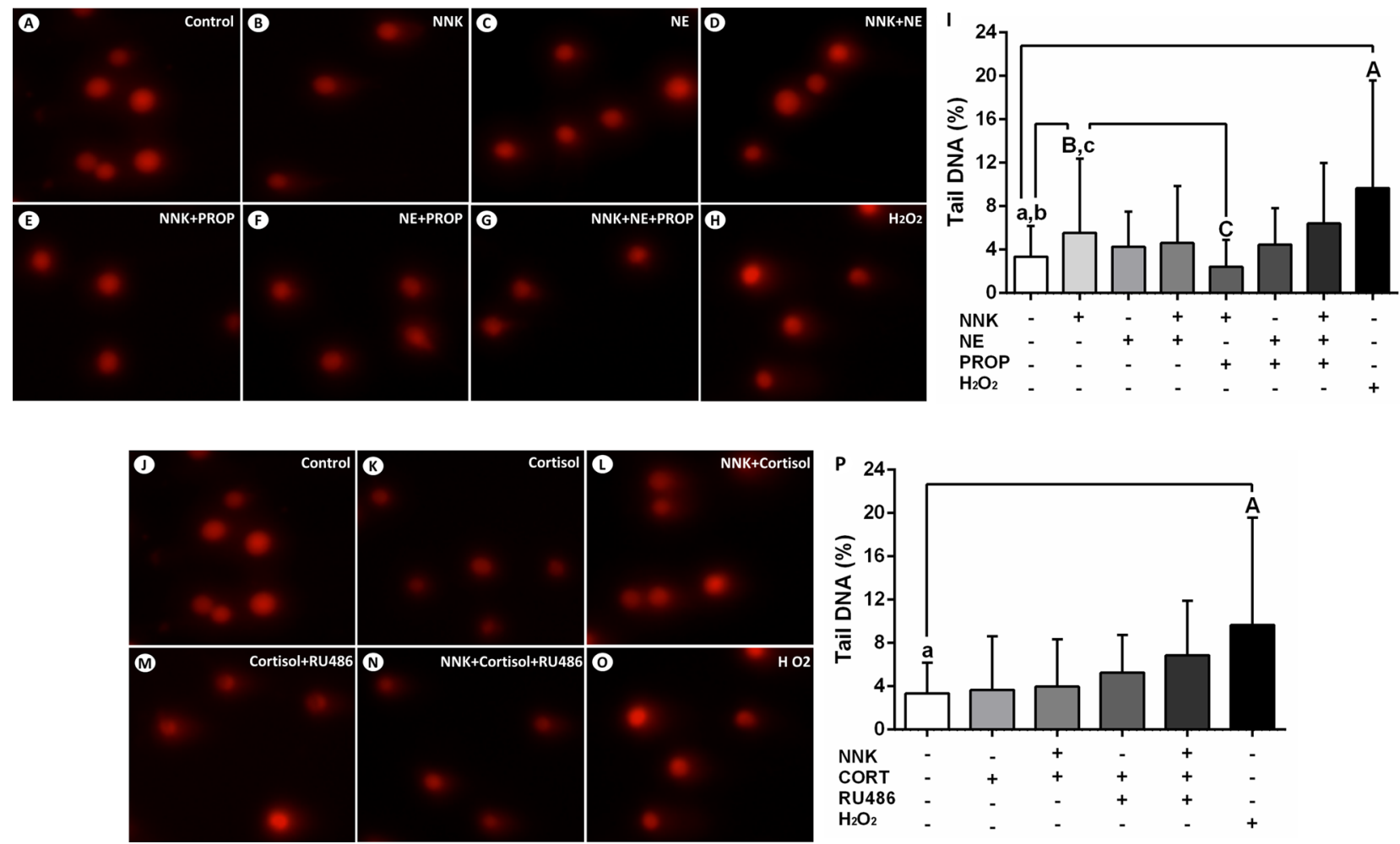

Figure 5. NNK promotes the oxidation of basis in the DNA of NOK-SI cells. (A) Control. (B) NNK. (C) Norepinephrine. (D) NNK and norepinephrine. (E) NNK and propranolol. (F) Norepinephrine and propranolol. (G) NNK, norepinephrine and propranolol. (H) $\mathrm{H}_{2} \mathrm{O}_{2}$ (positive control). (I) Cells treated with $\mathrm{H}_{2} \mathrm{O}_{2}$ or NNK exhibited an increase in the DNA damage, when compared to untreated cells after exposure to FPG enzyme. Beta-adrenergic antagonist propranolol blocked this effect. Norepinephrine in the presence or absence of NNK did not induce significant oxidation of basis. Cortisol did not promote significant oxidative DNA damage. (J) Control. (K) Cortisol. (L) NNK and cortisol. (M) Cortisol e RU486. (N) NNK, cortisol and RU486. (O) $\mathrm{H}_{2} \mathrm{O}_{2}$ (positive control). (P) $\mathrm{H}_{2} \mathrm{O}_{2}$ promoted DNA damage in oral keratinocytes. Cells treated with cortisol alone or combined with NNK did not show significant changes regarding the oxidation of basis. The results are expressed as the mean \pm standard deviation (SD). Upper- and lower cases equal letters indicate a statistically significant difference $(p<0.0001) . \mathrm{H}_{2} \mathrm{O}_{2}=$ hydrogen peroxide. $\mathrm{NNK}=4$ (N-metil- $\mathrm{N}$-nitrosamine)1-(3-piridil)-butano-1-one). $\mathrm{NE}=$ norepinephrine. $\mathrm{PRO} p=$ propranolol. $\mathrm{CORT}=$ cortisol. $\mathrm{NNK}, \mathrm{NE}, \mathrm{PROP}$ and RU486 were used at $10 \mu \mathrm{M}$. CORT was used at $100 \mathrm{nM}$. NOK-SI cells were exposed to NNK and/or stress hormones in the presence or absence of their antagonists for $72 \mathrm{~h}$.

A

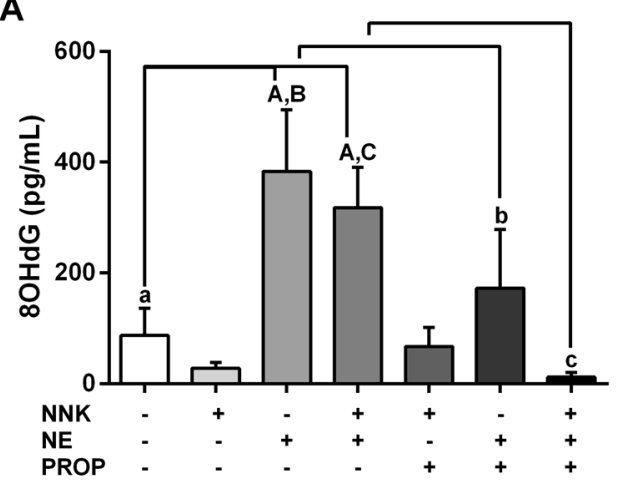

B

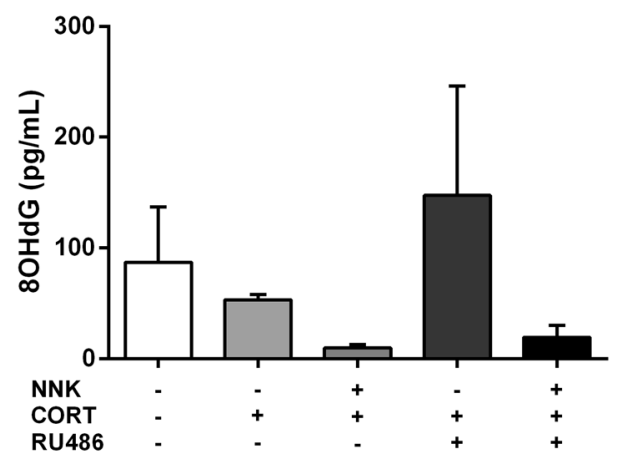

Figure 6. Effects of stress hormones on oxidative DNA damage in oral epithelial cells. (A) Norepinephrine up-regulated the $8 \mathrm{OHdG}$ levels in the presence or absence of carcinogen NNK. Beta-blocker propranolol inhibited the increased oxidative DNA damage caused by the hormone combined to NNK. (B) Cortisol did not change the $8 \mathrm{OHdG}$ levels secreted by the NOK-SI cells. The results are expressed as the mean \pm standard deviation (SD). Upper- and lower cases equal letters indicate a statistically significant difference $(p<0.05)$. $\mathrm{NNK}=4$ (N-metil-N-nitrosamine)-1-(3-piridil)-butano-1-one). $\mathrm{NE}=$ norepinefrina. $\mathrm{PRO} p=$ propranolol. CORT $=$ cortisol. NNK, NE, PROP and RU486 were used at $10 \mu \mathrm{M}$. CORT was used at $100 \mathrm{nM}$. NOK-SI cells were exposed to NNK and/or stress hormones in the presence or absence of their antagonists for $72 \mathrm{~h}$. 
adrenergic hormone in the presence or absence of NNK also promoted oxidative DNA damage resulting in a higher secretion of $8 \mathrm{OHdG}$ levels. This event was dependent of beta-adrenergic receptors. Another investigation found higher $8 \mathrm{OHdG}$ cellular levels in the DNA genomic of cardiac myoblasts after exposure to norepinephrine $\mathrm{e}^{28}$. $8 \mathrm{OHdG}$ has been considered the most common mutagenic biomarker associated to oxidative DNA damage ${ }^{2}$. It is closely related to the development of several types of cancer in humans and has also been used to estimate the DNA damage after exposure to carcinogenic agents ${ }^{29}$. In oral cancer patients, elevated salivary 8 OHdG levels have already been related to tumor progression and also seem to be involved in the pathogenesis of the disease ${ }^{30,31}$. The increased $8 \mathrm{OHdG}$ immunoexpression in non-tumor tissues contribute to the chemical oral carcinogenesis in preclinical models ${ }^{32,33}$.

In the current study, norepinephrine combined to nitrosamine NNK inhibited the apoptosis of NOK-SI cells by decreasing the activity of caspases 3 and 7. This inhibition would permit an uncontrolled proliferation of keratinocytes with damaged DNA, whose tumorigenic mutations could lead to the oral cancer development. The reduced expression of caspase 3 in oral cancer tissues has been related to malignant transformation ${ }^{34}$. A recent investigation demonstrated that norepinephrine protected against apoptosis of mesenchymal stem cells by inhibiting the expression of caspase 3 via $\mathrm{AKT} / \mathrm{BCL}-2^{11}$. It has also been suggested that norepinephrine regulates cell apoptosis through the activation of cAMP/PKA pathway via beta-adrenergic receptors ${ }^{35}$. There is substantial evidence that norepinephrine released from circulating blood and local sympathetic nerve fibers bind to betaadrenergic receptors on the cell membrane and induce the synthesis of cAMP, responsible for triggering oncogenic mechanisms ${ }^{35}$. cAMP activates PKA that phosphorylates several proteins including transcription factors of the ATF/CREB and GATA families ${ }^{35,36}$. Moreover, cAMP-induced up-regulation of Exchange Protein activated by Adenylyl Cyclase (EPAC) triggers the Ras/Raf/ MEK/ERK pathway regulating the transcription factors of the AP1 and ETS families ${ }^{35,37}$. In malignant cells, all these mechanisms mediated by cAMP influence the production of cytokines and growth factors, as well as cell morphology, motility and proliferation ${ }^{35}$. Beta-adrenergic signaling activated by the norepinephrine may also up-regulate the phosphorylation of the transcription factor STAT3, which modulates tumorigenic pathways ${ }^{38}$.

In epithelial cells of the upper aerodigestive tract, DNA damage promoted by tobacco-specific carcinogenic substances has been considered a crucial event for malignant transformation ${ }^{5}$. In the current study, NOK-SI cells were treated with the tobacco-specific nitrosamine NNK at a tumorigenic concentration commonly found in chronic smokers ${ }^{39}$. Although TUNEL assay has shown that nitrosamine did not induce significant fragmentation of the acid nucleic in these cells, comet assay demonstrated that NNK promotes single-strand breaks and alkali-label side breaks in the DNA of NOK-SI cells. In addition, NNK also induced the oxidation of basis in the presence of FPG. All genotoxic effects were mediated via beta-adrenergic receptors. These findings suggest that a long period of exposure to NNK would be needed to promote the induction of malignant phenotype in these cells. In bronchial epithelial cells, Shen et al. ${ }^{40}$, for example, induced a malignant phenotype after $192 \mathrm{~h}$ of exposure to nitrosamine. In our study, TUNEL assay showed that NNK almost inhibited the genotoxic effect caused by the norepinephrine while comet assay demonstrated that chemical carcinogen in the presence of norepinephrine did not promote significant DNA damage. This can be explained due to a decrease in the sensitivity of the beta-adrenergic receptors that may be downregulated when they are exposed to several agonists, such as catecholamines and $\mathrm{NNK}^{6}$. In human cells, NNK is enzymatically converted into metabolites, which bind to the DNA molecule and induce tumorigenic mutations ${ }^{5,6}$. These genotoxic effects can be mediated by nicotinic acetylcholine and beta-adrenergic receptors ${ }^{6}$. Although the tumorigenic action of nicotinic receptors induced by the NNK binding has been demonstrated in oral epithelial cells ${ }^{41-44}$, the role of beta-adrenergic signaling activated by the nitrosamine still need to be investigated. In other types of normal epithelial cells ${ }^{45,46}$, the tumorigenic action of beta-adrenergic receptors induced by NNK binding has already been evaluated. Beta-adrenergic receptors activated by the nitrosamine may mediate, for example, the levels of ERK1/2 MAP kinases in mammary cells ${ }^{45}$. In small airway cells, beta-adrenergic signaling activation by NNK can up-regulate ERK1/2 and ATF1/CREB phosphorylation via $\mathrm{PKA}^{46}$.

Cortisol secreted into the circulation binds to the glucocorticoid receptor in the cytoplasm and translocate it to the nucleus where they modulate the transcription of several genes by associating to DNA response elements and/or to other transcription factors ${ }^{47}$. Cortisol may lead to phosphorylation of MDM2 that down-regulates the function of the tumor suppression protein p53, mediator responsible for regulating several mechanisms associated to the DNA repair ${ }^{2,25}$. The persistent accumulation of DNA damage enhances the risk of malignant transformation predisposing the tumor cell development ${ }^{2}$. These findings concerning the MDM2/p53 signaling pathway were demonstrated in mouse embryonic fibroblasts after treatment of the cells with corticosterone, a glucocorticoid similar to cortisol found in mice and rats $^{25}$. Another investigation showed that cortisol at $1000 \mathrm{nM}$, considered a pharmacological concentration, promoted approximately a four to five-fold increase in DNA damage of 3T3 mouse fibroblasts after $10 \mathrm{~min}$ of exposure to the hormone, and this effect was reversed using antagonist RU486 ${ }^{3}$. Our results showed that cortisol at $100 \mathrm{nM}$ promoted single-strand breaks and alkalilabel side breaks in the DNA of oral epithelial cells and these effects were inhibited partially and totally, by the glucocorticoid receptor antagonist RU486 in the absence or presence of NNK, respectively. In the presence of FPG, cortisol did not induce significant DNA damage in NOK-SI cells. These results suggest that cortisol may not be acting only on glucocorticoid receptors. The induction of DNA damage in oral keratinocytes could be modulated by the activation of other mechanisms triggered by the glucocorticoid, including those mediated by the mineralocorticoid receptors.

The current study showed that a higher $\gamma \mathrm{H} 2 \mathrm{AX}$ cellular accumulation was detected after exposure to NNK and/or glucocorticoid, and this event was completely reversed by RU486 treatment. In the current study, the concentration designed for cortisol simulated chronic stress conditions ${ }^{19}$. Recent studies have shown that cortisol exposure also promote an accumulation of $\gamma \mathrm{H} 2 \mathrm{AX}$ in breast cancer cells ${ }^{8,48,49}$. In these investigations, the analysis of $\gamma \mathrm{H} 2 \mathrm{AX}$ phosphorylation was used as an indicator of DNA damage induced by the cortisol, whose 
effects were blocked with RU486 use $\mathrm{8}^{8,48,49}$. These findings suggest that cortisol produces genotoxic effects mediated via glucocorticoid receptor. Currently, there is a lack of consensus regarding the cortisol concentration to induce these effects in normal and tumor cells. The quantification of $\gamma \mathrm{H} 2 \mathrm{AX}$ levels can also be used to determinate the DNA lesions resulting from exposure to environmental carcinogens such as nitrosamines ${ }^{10,50}$. In our results, NNK promoted an increase in the $\gamma \mathrm{H} 2 \mathrm{AX}$ nuclear expression in oral keratinocytes and this genotoxic effect was abrogated by the beta-adrenergic blockade with propranolol. In oral carcinogenesis, tissue $\gamma \mathrm{H} 2 \mathrm{AX}$ immunoexpression increases significantly before malignant transformation being considered an indicator for oral cancer development ${ }^{51}$. In the TUNEL assay, NNK inhibited the DNA fragmentation induced by the cortisol. A rapid metabolization of the glucocorticoid in the presence of NNK could have avoid this more severe genotoxic effect. The enzyme $11 \beta$-Hydroxysteroid dehydrogenase type 1 (11 $\beta$-HSD 1 ), which is involved in the metabolism of cortisol can also metabolize the tobacco-specific nitrosamine $\mathrm{NNK}^{52}$. The presence of NNK in the culture medium could have increased the production of $11 \beta-$ HSD 1 in the NOK-SI cells and consequently the consumption of cortisol.

The current study shows that cortisol promotes anti-apoptotic effects in NOK-SI cells by reducing the activity of caspases 3 and 7. In addition to DNA damage, these effects induced by the glucocorticoid could contribute to a proliferative malignant behavior of the oral keratinocytes. Glucocorticoid receptor antagonist RU486 did not reverse the anti-apoptotic effects induced by the cortisol. Other mechanisms triggered by the glucocorticoid could be modulating the activity of caspases 3 and 7 in the oral keratinocytes, including the activation of mineralocorticoid receptors. In breast cancer cell lines, dexamethasone (a glucocorticoid) at $1000 \mathrm{nM}$ inhibited chemotherapyinduced apoptosis and promoted the gene expression of SGK1 and MKP1, whose proteins are associated to cell survival $^{12}$. After glucocorticoid exposure, proapoptotic genes, caspases 3,8 and 9 and pro-apoptotic BCL-2 family members were downregulated ${ }^{12}$. In another study, dexamethasone inhibited the activity of caspases in lung and cervical cancer cell lines preventing therapy-induced tumor reduction in orthotopic model ${ }^{53}$. Similarly to these findings, the current study demonstrates that cortisol in a stress concentration may affect cell death of normal oral keratinocytes. These cells might then proliferate continuously with damaged DNA becoming malignant.

This study showed that stress hormones may induce DNA damage of oral keratinocytes. In our experiments, we have succeed in evaluating the genotoxic role of each hormone in the presence or absence of NNK, which is not possible to verify clinically. Although this study has brought advances regarding the use of in vitro model to better understand the role of stress hormones on the initial steps of oral carcinogenesis process in humans, it has also some limitations that need to be considered. It was not possible to determine the minimal amount of damaged DNA responsible to induce the biological responses. In addition, the dynamic binding between stress hormones and their receptors as well as the regulation of signaling pathways by the beta-adrenergic receptors in the presence of NNK and/or norepinephrine were not evaluated in the current study. The cells were also not tested with different concentrations of cortisol once it seems to have dual effects on tumorigenic processes, as we previously reported ${ }^{18,19}$. From the results of the current study, the genotoxic effects of stress hormones could be investigated in primary cultures or other oral keratinocytes cell lines.

To date, no study has evaluated the genotoxic effects of stress hormones associated to tobacco-specific nitrosamines on the promotion of genomic lesions in normal oral keratinocytes. Our findings show that high concentrations of norepinephrine and cortisol that simulate chronic stress cause expressive DNA damage of NOK-SI cells, predisposing them to malignant transformation. The occurrence of this event may be confirmed by the evaluation of the increased cellular levels of biomarkers associated to the DNA damage. The genotoxic effects caused by the stress hormones in epithelial cells could increase the risk of developing oral cancer.

\section{Material and methods}

Cells and culture conditions. Normal Oral Keratinocyte-Spontaneously Immortalized (NOK-SI) cell line was kindly provided by the Dr. Aline Satie Takamiya (São Paulo State University-UNESP, Araçatuba, São Paulo, Brazil). NOK-SI cells were cultured in Dulbecco Modified Eagle Medium (DMEM; Gibco, Carlsbad, CA, EUA) containing $4 \mathrm{mM} \mathrm{L}$-glutamine, $1.5 \mathrm{~g} / \mathrm{L}$ sodium bicarbonate and $4.5 \mathrm{~g} / \mathrm{L}$ glucose. All reagents used in this study were purchased from Sigma Aldrich (St. Louis, MO, USA). The culture medium was supplemented with $10 \%$ fetal bovine serum (FBS), $100 \mu \mathrm{g} / \mathrm{mL}$ streptomycin, $100 \mu \mathrm{g} / \mathrm{mL}$ penicillin and $0.1 \%$ gentamicin. NOK-SI cells were grown in $75-\mathrm{cm}^{2}$ culture flasks (Greiner Bio-One, Kremsmünster, Austria) at $37^{\circ} \mathrm{C}$ in humidified atmosphere of $5 \%(\mathrm{v} / \mathrm{v}) \mathrm{CO}_{2}$. After reaching approximately $70 \%$ cell density, the cells were trypsinized, seeded in 6-well plates and then maintained under the same conditions. In these plates, NOK-SI cells were stimulated with NNK (CASNr 64091-91-4) and/or stress hormones, norepinephrine (CASNr 3414-63-9) or cortisol (CASNr 50-237), after reaching about 50\% cell density. All reagents were purchased from Merck (Merck KGaA, Darmstadt, Germany).

Carcinogen and hormone treatment. The growth medium was replaced with NNK and/or norepinephrine at $10 \mu \mathrm{M}$ or cortisol at $100 \mathrm{nM}$, according to previous studies ${ }^{19,53}$. These concentrations simulate chronic stress conditions in humans. NNK and stress hormones were added at the same time in the groups which carcinogen was in the presence of norepinephrine or cortisol. The blocking of hormone receptors was performed by pre-incubating cells with beta-adrenergic receptor antagonist propranolol and glucocorticoid receptor antagonist RU486. Both antagonists were diluted in the culture medium to achieve the concentration of $10 \mu \mathrm{M}$. Cells were incubated in the presence of antagonists for $1 \mathrm{~h}$ prior to the addition of NNK and/or norepinephrine or cortisol. NOK-SI cells were cultured without FBS overnight and then exposed to the NNK and/or hormone for $4 \mathrm{~h}$ in culture medium without FBS. Moreover, cells were also cultured with $10 \%$ FBS and stimulated with carcinogen and/or hormone for $72 \mathrm{~h}$ in a culture medium with $10 \%$ FBS. In this case, the stimuli were replaced every $24 \mathrm{~h}$ along with the renewal of the culture medium. Preliminary experiments showed that the suppression 
of FBS for $72 \mathrm{~h}$, even in the presence of stress hormones, promoted morphological changes and high mortality rate in NOK-SI cells.

Terminal deoxynucleotidyl transferase dUTP nick-end labelling (TUNEL assay). The cells were washed in phosphate-buffered saline solution (PBS) with $1 \mathrm{mg} / \mathrm{mL}$ of polyvinyl alcohol (PBS/PVA) and fixed using a $4 \%$ paraformaldehyde solution for $1 \mathrm{~h}$ at room temperature. Then, NOK-SI cells were permeabilized using $0.5 \%$ Triton X-100 for $30 \mathrm{~min}$ and washed with PBS/PVA. For the positive control, untreated cells were incubated with DNAse I $(50 \mathrm{IU} / \mathrm{mL})$ for $1 \mathrm{~h}$ at room temperature while cells from the experimental groups were maintained in PBS/PVA. Cells were incubated in $30 \mu \mathrm{L}$ of TUNEL reaction mixture (In-Situ Cell Death Detection Kit (Roche Diagnostics Corp., Indianapolis, IN, USA) for $1 \mathrm{~h}$ at room temperature, according to the manufacturer's recommendations. For the negative control, untreated cells were incubated with label solution only. The cells were washed in PBS/PVA and stained with Hoechst $33342(1 \mu \mathrm{g} / \mathrm{mL})$ for $10 \mathrm{~min}$ at room temperature. Then, they were washed again in PBS/PVA and transferred to the glass slides using the Vectashield mounting medium (Vector Laboratories, Burlingame, CA, USA). Coverslips were placed. The cells were analyzed using an inverted epifluorescence microscope (Olympus America Inc, Center Valley, PA, USA). The percentage of TUNEL-positive cells showing fragmented DNA was then determined by a blinded researcher.

Activity of caspases-3 and -7. The activity of caspases- 3 and -7 was measured in the NOK-SI cells using the Image-iT LIVE Red Caspase-3 and -7 Detection Kit (Molecular Probes, Invitrogen, OR, USA) according to the manufacturer's instructions. The cells were incubated in $10-\mu \mathrm{L}$ of a fluorescent inhibitor of caspases-3 and 7 for $1 \mathrm{~h}$ at $37^{\circ} \mathrm{C}$ in a humid chamber. Cells were washed with PBS buffer solution and fixed in $4 \%$ paraformaldehyde solution for $40 \mathrm{~min}$ at room temperature. The cells were then stained with Hoechst $33,342(1 \mu \mathrm{g} / \mathrm{mL})$ and the slides mounted with Vectashield (Vector Laboratories, Burlingame, CA, USA). Stained cells were photographed using an inverted microscope (Olympus America Inc, Center Valley, PA, USA). A blinded researcher to the experimental groups quantified the fluorescence signal intensities (pixels) of the stained cells in the recorded images running the ImageJ software (National Institutes of Health, Bethesda, MD, USA).

Single cell gel electrophoresis (comet assay). Adherent cells were trypsinized from the plates, mixed in $0.5 \%$ low-melting agarose and placed in glass slides pre-coated with $1 \%$ agarose gel. The slides were immersed in lysis solution ( $1 \mathrm{M}$ Tris, $1 \mathrm{M} \mathrm{NaCl}, 1 \mathrm{M}$ Na2EDTA, $1 \%$ Triton X-100) with proteinase $\mathrm{K}$ for $2 \mathrm{~h}$ at $50^{\circ} \mathrm{C}$. Then, they underwent electrophoresis at $25 \mathrm{~V}$ for $30 \mathrm{~min}$ and neutralized with $0.4 \mathrm{M}$ Tris- $\mathrm{HCl}$ for $5 \mathrm{~min}$. The cells were then stained with ethidium bromide $(2 \mu \mathrm{g} / \mathrm{mL})$ and photographed using an inverted microscope (Olympus America Inc, Center Valley, PA, USA) with an excitation wavelength of $495 \mathrm{~nm}$ and an emission wavelength of $520 \mathrm{~nm}$. In each group, a total of 100 cells was analyzed. The percentage of DNA in the comet tail was determined using the CASP software (University of Wroclaw, Wroclaw, Poland) by a blinded researcher to the experimental groups.

FPG (DNA-formamidopyrimidine glycosylase)-modified comet assay. As described above, cells were firstly mixed in low-melting agarose, placed in glass slides pre-coated with agarose gel and immersed in lysis solution. The slides were washed in the FPG buffer (40 mM HEPES, $0.1 \mathrm{M} \mathrm{KCl}, 0.5 \mathrm{mM}$ EDTA, pH 8 ) and incubated with the enzyme $(1: 3000)$ or buffer for $45 \mathrm{~min}$ at $37^{\circ} \mathrm{C}$. Then, they were subjected to electrophoresis, neutralized, stained with ethidium bromide, photographed and analyzed as described for the conventional comet assay. The level of FPG-sensitive sites was calculated as the difference in percentage (\%) of tail DNA between FPG-treated cells and control cells (not-treated with the enzyme).

Immunoexpression of phospho- $\mathrm{H} 2 \mathrm{AX}(\mathrm{\gamma H} 2 \mathrm{AX})$. Cells were fixed with $4 \%$ paraformaldehyde solution in glass-bottom tissue culture plates and maintained in methanol for $20 \mathrm{~min}$ at $4{ }^{\circ} \mathrm{C}$. Non-specific binding sites were then blocked by using $1 \%$ bovine serum albumin (BSA) for $2 \mathrm{~h}$ at room temperature. Cells were incubated overnight at $4{ }^{\circ} \mathrm{C}$ with primary antibody for anti-phospho-H2AX (1:200; Cell Signaling Technology, Beverly, MA, USA). Then, the secondary antibody was incubated for $1 \mathrm{~h}$ at room temperature. The cells were stained with Hoechst $33342(1 \mu \mathrm{g} / \mathrm{mL}$ ) and the slides mounted with Vectashield (Vector Laboratories, Burlingame, CA, USA). NOK-SI cells were photographed using an inverted microscope (Olympus America Inc, Center Valley, PA, USA) and a blinded researcher to the experimental groups quantified the fluorescence signal intensities (pixels) of the stained cells in the recorded images by using the ImageJ software (National Institutes of Health, Bethesda, MD, USA).

Measurement of 8-hydroxy-2'-deoxyguanosine (8OHdG) content. The 8-hydroxy-2'deoxyguanosine (8OHdG) levels were measured in the culture medium using a specific kit (DNA/RNA Oxidative Damage; Cayman Chemical, Michigan, USA) by the method Enzyme-Linked Immunosorbent Assay (ELISA). The ELISA assay sensitivity was $30 \mathrm{pg} / \mathrm{mL}$ for $8 \mathrm{OHdG}$. This assay was performed in triplicate according to the manufacturer's recommendations.

Statistical analysis. GraphPad Prism 8.21 (GraphPad Software Inc., San Diego, CA, USA) was used to perform statistical analysis. The one-way analysis of variance (ANOVA) with post-hoc Tukey test for multiple comparisons evaluated possible differences between the groups. The results were presented as mean \pm standard deviation (SD). Differences were considered statistically significant when $p<0.05$. 


\section{Data availability}

The datasets generated during and/or analyzed during the current study are available from the corresponding author on reasonable request.

Received: 18 November 2020; Accepted: 8 September 2021

Published online: 05 October 2021

\section{References}

1. Cohen, S., Janicki-Deverts, D. \& Miller, G. E. Psychological stress and disease. JAMA 298, 1685-1687 (2007).

2. Jenkins, F. J., Van Houten, B. \& Bovbjerg, D. H. Effects on DNA damage and/or repair processes as biological mechanisms linking psychological stress to cancer risk. J. Appl. Biobehav. Res. 19, 3-23 (2014).

3. Flint, M. S., Baum, A., Chambers, W. H. \& Jenkins, F. J. Induction of DNA damage, alteration of DNA repair and transcriptional activation by stress hormones. Psychoneuroendocrinology 32, 470-479 (2007).

4. Flint, M. S. et al. Chronic exposure to stress hormones promotes transformation and tumorigenicity of 3T3 mouse fibroblasts. Stress. 16, 114-121 (2013).

5. Pfeifer, G. P. et al. Tobacco smoke carcinogens, DNA damage and p53 mutations in smoking-associated cancers. Oncogene 21, 7435-7451 (2002)

6. Schuller, H. M. Nitrosamines as nicotinic receptor ligands. Life Sci. 80, 2274-2280 (2007).

7. Hara, M. R. et al. A stress response pathway regulates DNA damage thro-ugh $\beta 2$-adrenoreceptors and $\beta$-arrestin-1. Nature 477, 349-353 (2011).

8. Flaherty, R. L. et al. Glucocorticoids induce production of reactive oxygen species/reactive nitrogen species and DNA damage through an iNOS mediated pathway in breast cancer. Breast Cancer Res. 19, 35 (2017).

9. Adachi, S., Kawamura, K. \& Takemoto, K. Oxidative damage of nuclear DNA in liver of rats exposed to psychological stress. Cancer Res. 53, 4153-4155 (1993).

10. Podhorecka, M., Skladanowski, A. \& Bozko, P. H2AX phosphorylation: its role in DNA damage response and cancer therapy. J. Nucleic Acids. 2010, 920161 (2010)

11. Kong, Y. et al. Norepinephrine protects against apoptosis of mesenchymal stem cells induced by high glucose. J. Cell. Physiol. 234, 20801-20815 (2019)

12. Wu, W. et al. Microarray analysis reveals glucocorticoid-regulated survival genes that are associated with inhibition of apoptosis in breast epithelial cells. Cancer Res. 64, 1757-1764 (2004).

13. Lu, J. Y. D. et al. The neuroprotective effect of nicotine in Parkinson's disease models is associated with inhibiting PARP-1 and caspase-3 cleavage. PeerJ. 5, e3933 (2017).

14. Pereira, R. M., Delany, A. M. \& Canalis, E. Cortisol inhibits the differentiation and apoptosis of osteoblasts in culture. Bone 28, 484-490 (2001).

15. Bray, F. et al. Global cancer statistics 2018: GLOBOCAN estimates of incidence and mortality worldwide for 36 cancers in 185 countries. CA Cancer J. Clin. 68, 394-424 (2018).

16. Bastos, D. B. et al. Circulating catecholamines are associated with biobehavioral factors and anxiety symptoms in head and neck cancer patients. PLoS One. 13, e0202515 (2018).

17. Xie, H. et al. Chronic stress promotes oral cancer growth and angiogenesis with increased circulating catecholamine and glucocorticoid levels in a mouse model. Oral Oncol. 51, 991-997 (2015).

18. Valente, V. B. et al. Stress hormones concentrations in the normal microenvironment predict risk for chemically induced cancer in rats. Psychoneuroendocrinology 89, 229-238 (2018).

19. Bernabé, D. G., Tamae, A. C., Biasoli, É. R. \& Oliveira, S. H. Stress hormones increase cell proliferation and regulates interleukin-6 secretion in human oral squamous cell carcinoma cells. Brain Behav. Immun. 25, 574-583 (2011).

20. Zhang, B. et al. The stress hormone norepinephrine promotes tumor progression through $\beta 2$-adrenoreceptors in oral cancer. Arch. Oral Biol. 113, $104712(2020)$.

21. Verza, F. A. et al. Social isolation stress facilitates chemically induced oral carcinogenesis. PLoS One. 16, e0245190 (2021).

22. Sun, F. et al. Adrenergic DNA damage of embryonic pluripotent cells via $\beta 2$ receptor signalling. Sci. Rep. 5, 15950 (2015).

23. Hara, M. R., Sachs, B. D., Caron, M. G. \& Lefkowitz, R. J. Pharmacological blockade of a $\beta(2)$ AR- $\beta$-arrestin-1 signaling cascade prevents the accumulation of DNA damage in a behavioral stress model. Cell Cycle 12, 219-224 (2013).

24. Jang, H. J., Boo, H. J., Lee, H. J., Min, H. Y. \& Lee, H. Y. Chronic stress facilitates lung tumorigenesis by promoting exocytosis of IGF2 in lung epithelial cells. Cancer Res. 76, 6607-6619 (2016).

25. Feng, Z. et al. Chronic restraint stress attenuates p53 function and promotes tumorigenesis. Proc. Natl. Acad. Sci. USA 109, 7013-7018 (2012).

26. Lamboy-Caraballo, R. et al. Norepinephrine-induced DNA damage in ovarian cancer cells. Int. J. Mol. Sci. 21, 2250 (2020).

27. Andersson, D. C. et al. Mitochondrial production of reactive oxygen species contributes to the $\beta$-adrenergic stimulation of mouse cardiomycytes. J. Physiol. 589, 1791-1801 (2011).

28. Thakur, A. et al. Norepinephrine-induced apoptotic and hypertrophic responses in H9-c2 cardiac myoblasts are characterized by different repertoire of reactive oxygen species generation. Redox. Biol. 5, 243-252 (2015).

29. Valavanidis, A., Vlachogianni, T. \& Fiotakis, C. 8-Hydroxy-2'-deoxyguanosine (8-OHdG): a critical biomarker of oxidative stress and carcinogenesis. J. Environ. Sci. Health C Environ. Carcinog. Ecotoxicol. Rev. 27, 120-139 (2009).

30. Bahar, G., Feinmesser, R., Shpitzer, T., Popovtzer, A. \& Nagler, R. M. Salivary analysis in oral cancer patients: DNA and protein oxidation, reactive nitrogen species, and antioxidant profile. Cancer 109, 54-59 (2007).

31. Kaur, J., Politis, C. \& Jacobs, R. Salivary 8-hydroxy-2-deoxyguanosine, malondialdehyde, vitamin C, and vitamin E in oral precancer and cancer: Diagnostic value and free radical mechanism of action. Clin. Oral Investig. 20, 315-319 (2016).

32. Soares, G. R. et al. Protective effects of purple carrot extract (Daucus carota) against rat tongue carcinogenesis induced by 4-nitroquinoline 1-oxide. Med. Oncol. 35, 54 (2018).

33. De Moura, C. F. G. et al. Evaluation of the chemopreventive activity of grape skin extract using medium-term oral carcinogenesis assay induced by 4-nitroquinoline 1-oxide. Anticancer Res. 39, 177-182 (2019).

34. Veeravarmal, V., Austin, R. D., Siddavaram, N., Thiruneelakandan, S. \& Nassar, M. H. Caspase-3 expression in normal oral epithelium, oral submucous fibrosis and oral squamous cell carcinoma. J. Oral Maxillofac. Pathol. 20, 445-452 (2016).

35. Cole, S. W. \& Sood, A. K. Molecular pathways: Beta-adrenergic signaling in cancer. Clin. Cancer Res. 18, 1201-1206 (2012).

36. Zhang, X. et al. Genome-wide analysis of cAMP-response element binding protein occupancy, phosphorylation, and target gene activation in human tissues. Proc. Natl. Acad. Sci. USA 102, 4459-4464 (2005).

37. Hollenhorst, P. C. RAS/ERK pathway transcriptional regulation through ETS/AP-1 binding sites. Small GTPases. 3, 154-158 (2012).

38. Landen, C. N. Jr. et al. Neuroendocrine modulation of signal transducer and activator of transcription-3 in ovarian cancer. Cancer Res. 67, 10389-10396 (2007). 
39. Maser, E., Friebertshäuser, J. \& Völker, B. Purification, characterization and NNK carbonyl reductase activities of 11beta-hydroxysteroid dehydrogenase type 1 from human liver: Enzyme cooperativity and significance in the detoxification of a tobacco-derived carcinogen. Chem Biol Interact. 143, 435-448 (2003).

40. Shen, Y. et al. Involvement of p53 mutation and mismatch repair proteins dysregulation in NNK-induced malignant transformation of human bronchial epithelial cells. Biomed. Res. Int. 2014, 920275 (2014).

41. Arredondo, J., Chernyavsky, A. I. \& Grando, S. A. Nicotinic receptors mediate tumorigenic action of tobacco-derived nitrosamines on immortalized oral epithelial cells. Cancer Biol. Ther. 5, 511-517 (2006).

42. Kalantari-Dehaghi, M., Bernard, H. U. \& Grando, S. A. Reciprocal effects of NNK and SLURP-1 on oncogene expression in target epithelial cells. Life Sci. 91, 1122-1125 (2012).

43. Arredondo, J., Chernyavsky, A. I. \& Grando, S. A. Overexpression of SLURP-1 and -2 alleviates the tumorigenic action of tobaccoderived nitrosamine on immortalized oral epithelial cells. Biochem. Pharmacol. 74, 1315-2119 (2007).

44. Arredondo, J., Chernyavsky, A. I. \& Grando, S. A. SLURP-1 and -2 in normal, immortallized and malignant oral keratinocytes. Life Sci. 80, 2243-2247 (2007).

45. Chen, Z. B. et al. Effects of tobacco-specific carcinogen 4-(methylnitrosamino)-1-(3-pyridyl)-1-butanone (NNK) on the activation of ERK1/2 MAP kinases and the proliferation of human mammary epithelial cells. Environ. Toxicol. Pharmacol. 22, 283-291 (2006).

46. Laag, E. et al. NNK activates ERK1/2 and CREB/ATF-1 via beta-1-AR and EGFR signaling in human lung adenocarcinoma and small airway epithelial cells. Int. J. Cancer. 119, 1547-1552 (2006).

47. Oakley, R. H. \& Cidlowski, J. A. The biology of the glucocorticoid receptor: new signaling mechanisms in health and disease. J. Allergy Clin. Immunol. 132, 1033-1044 (2013).

48. Reeder, A. et al. Stress hormones reduce the efficacy of paclitaxel in triple negative breast cancer through induction of DNA damage. Br. J. Cancer. 112, 1461-1470 (2015).

49. Flaherty, R. L. et al. Stress hormone-mediated acceleration of breast cancer metastasis is halted by inhibition of nitric oxide synthase. Cancer Lett. 459, 59-71 (2019).

50. Zhang, S. et al. Genotoxicity analysis of five particle matter toxicants from cigarette smoke based on $\gamma \mathrm{H} 2 \mathrm{AX}$ assay combined with Hill/Two-component model. Environ. Toxicol. Pharmacol. 58, 131-140 (2018).

51. Chou, S. J. \& Alawi, F. Expression of DNA damage response biomarkers during oral carcinogenesis. Oral Surg. Oral Med. Oral Pathol. Oral Radiol. Endod. 111, 346-353 (2011).

52. Herr, I. et al. Glucocorticoid cotreatment induces apoptosis resistance toward cancer therapy in carcinomas. Cancer Res. 63, 3112-2310 (2003).

53. Liu, Y. et al. Tumorigenesis of smoking carcinogen 4-(methylnitrosamino)-1-(3-pyridyl)-1-butanone is related to its ability to stimulate thromboxane synthase and enhance stemness of non-small cell lung cancer stem cells. Cancer Lett. 370, 198-206 (2016).

\section{Acknowledgements}

This research was supported by the São Paulo Research Foundation (FAPESP, Grant Nos. 2016/25255-0 and 2017/07784-8) and financed in part by the Coordenação de Aperfeiçoamento de Pessoal de Nível Superior (CAPES, Finance Code 001).

\section{Author contributions}

V.B.V. Data curation; Formal analysis; Funding acquisition; Investigation; Methodology; Writing the original draft. D.M.C., G.M.K. and G.B.N. Data curation; Investigation; Methodology. K.C.T., E.R.B. and G.I.M. Visualization, Investigation and Resources. G.Z.M. and S.H.P.O. Data curation; Formal analysis; Investigation; Methodology; Project administration; Resources; Review and editing. D.G.B. Conceptualization, Data curation, Formal analysis, Funding acquisition, Investigation, Project administration, Resources, Review and editing.

\section{Competing interests}

The authors declare no competing interests.

\section{Additional information}

Correspondence and requests for materials should be addressed to D.G.B.

Reprints and permissions information is available at www.nature.com/reprints.

Publisher's note Springer Nature remains neutral with regard to jurisdictional claims in published maps and institutional affiliations.

(c) (i) Open Access This article is licensed under a Creative Commons Attribution 4.0 International License, which permits use, sharing, adaptation, distribution and reproduction in any medium or format, as long as you give appropriate credit to the original author(s) and the source, provide a link to the Creative Commons licence, and indicate if changes were made. The images or other third party material in this article are included in the article's Creative Commons licence, unless indicated otherwise in a credit line to the material. If material is not included in the article's Creative Commons licence and your intended use is not permitted by statutory regulation or exceeds the permitted use, you will need to obtain permission directly from the copyright holder. To view a copy of this licence, visit http://creativecommons.org/licenses/by/4.0/.

(C) The Author(s) 2021 